\title{
Unsur Keinggerisan dalam Tajuk Utama Katalog Bercetak Versi Terjemahan Berbahasa Melayu
}

\author{
Anglicism in the Translated Version of Headlines in \\ Malay Printed Catalogues
}

\author{
ANIS SHAHIRAH ABDUL SUKUR \\ School of Humanities, Universiti Sains Malaysia, 11800 USM Pulau Pinang, Malaysia \\ sha_anis@usm.my
}

Published online: 20 April 2018

To cite this article: Abdul Sukur, A.S. 2018. Unsur keinggerisan dalam tajuk utama katalog bercetak versi terjemahan berbahasa Melayu. KEMANUSIAAN the Asian Journal of Humanities 25(1): 95-114, https://doi.org/10.21315/kajh2018.25.1.5

To link to this article: https://doi.org/10.21315/kajh2018.25.1.5

\begin{abstract}
Abstrak. Makalah ini membincangkan isu keinggerisan yang wujud dalam katalog bercetak berbahasa Melayu versi terjemahan. Data kajian terdiri daripada 2,064 tajuk utama yang dikutip secara manual daripada katalog bercetak Cosway dan Avon. Kajian ini menerapkan pendekatan eklektik untuk menganalisis data kajian yang dikumpulkan. Bagi tujuan menganalisis data, kajian ini mengaplikasikan kategori kata pinjaman Heah (1989) dan Puteri Roslina (2012) yang diubah suai, serta definisi kata pinjaman oleh Haugen (1972) untuk mengelaskan unsur keinggerisan yang wujud dalam tajuk utama. Dapatan kajian menunjukkan bahawa langkah penterjemahan, khususnya melalui penggunaan prosedur peminjaman telah mewujudkan unsur keinggerisan dalam tajuk utama versi terjemahan. Kategori kata pinjaman pula boleh dikategorikan kepada enam kategori, iaitu kata pinjaman tidak asimilasi, kata pinjaman separa asimilasi, kata pinjaman asimilasi lengkap, kata pinjaman asimilasi ortografi, kata pinjaman majmuk asimilasi dan kata pinjaman asing yang dipendekkan. Berdasarkan kajian yang telah dilakukan, implikasi kajian ini memperlihatkan penterjemahan menyumbang ke arah kesan keinggerisan dalam katalog bercetak versi terjemahan berbahasa Melayu, yang boleh dihuraikan daripada segi kesan positif dan negatif.
\end{abstract}

Kata kunci dan frasa: keinggerisan, kata pinjaman, penterjemahan teks media, tajuk utama, katalog bercetak

Abstract. This paper discusses Anglicism issues in Malay translations of printed catalogues in English. The research data is made up of 2,064 headlines collected manually from Cosway and Avon printed catalogues. This study uses an eclectic approach to analyse the research data collected. Therefore, for the purpose of data collection and analysis, this study utilises and modifies the loanword category in the Malay language proposed by Heah

(C) Penerbit Universiti Sains Malaysia, 2018. This work is licensed under the terms of the Creative Commons Attribution (CC BY) (http://creativecommons.org/licenses/by/4.0/). 
(1989) and Puteri Roslina (2012), and adopts Haugen's (1972) definition of loanwords, to classify Anglicism that exist in the translation version of advertising headlines. The findings show that translation, especially through the transference procedure, contributes to Anglicism in the said headlines. Loanwords can be classified into six types, namely unassimilated loanword, partially assimilated loanword, wholly assimilated loanword, orthographically assimilated loanword, assimilated compound loanword and truncated loanword. Based on the study conducted, the implication is translation contributes towards the existence of Anglicism in the translated version of Malay printed catalogues, which can be explained from positive and negative impacts.

Keywords and phrases: Anglicism, loanword, media text translation, headline, printed catalogue

\section{Pengenalan dan Latar Belakang}

Istilah Anglicism atau padanan katanya dalam bahasa Melayu, iaitu "keinggerisan" digunakan buat pertama kali pada kurun ke-17, dan ia merujuk kepada ungkapan daripada bahasa Inggeris yang digunakan dalam bahasa lain (Fischer 2008). Walaupun istilah ini berkait rapat dengan perkataan England secara etimologi, Anglicism juga merujuk kepada peminjaman daripada semua jenis variasi bahasa Inggeris. Menurut Majlinda (2014), Anglicism merujuk kepada objek, idea atau konsep sebagai rujukan bagi tamadun Barat. Perkataan yang mempunyai unsur Anglicism tidak semestinya berasal daripada bahasa Inggeris, sebaliknya merupakan perkataan yang sebati dengan sistem bahasa Inggeris dan diterima pakai sebagai kosa kata bahasa Inggeris.

Isu keinggerisan turut berlaku dalam industri periklanan tempatan, iaitu bidang perusahaan perkhidmatan yang digerakkan oleh media cetak. Fenomena keinggerisan daripada segi penggunaan gaya dan bahasa Inggeris ini terjadi disebabkan oleh Malaysia pernah dijajah oleh negara Barat, di samping faktor kemasukan pelbagai produk luar negara ke dalam Malaysia. Pengaruh Inggeris misalnya boleh diteliti dalam bahasa dan kandungan iklan seperti penggunaan kata serapan bahasa Inggeris, pemilihan model Barat atau berwajah pan-Asia, pemaparan gaya hidup masyarakat Barat menerusi penuturan dialog dan cara masyarakat Barat berpakaian (Mohd. Sidin dan Noorbathi 1993; Maserah dan Idris 2012).

Daripada konteks penterjemahan, isu keinggerisan bukanlah sesuatu isu yang asing. Kebanyakan iklan berbahasa Melayu dihasilkan secara penterjemahan daripada bahasa Inggeris yang dianggap sebagai lingua franca bidang periklanan (Haslina 2006). Penterjemahan merupakan pemindahan makna daripada bahasa sumber ke dalam bahasa sasaran tanpa melibatkan sebarang perubahan makna (Larson 
1984). Sekiranya penterjemah menterjemahkan iklan berbahasa Inggeris ke dalam bahasa Melayu, maka penterjemah wajar memastikan makna yang terkandung dalam bahasa Inggeris berjaya disampaikan. Hal ini juga bermaksud perkara yang dipentingkan adalah makna yang terkandung dalam iklan dan bukannya bentuk atau gaya bahasa Inggeris.

Asmah (1984) mengutarakan permasalahan terjemahan iklan dalam bahasa Melayu yang "berbau" keinggerisan. Walau bagaimanapun, huraian Asmah terbatas pada peminjaman perkataan bahasa Inggeris dan penyalinan struktur ayat bahasa Inggeris dalam terjemahan iklan berbahasa Melayu. Kajian ini tidak menjelaskan secara teliti kategori kata pinjaman bahasa Inggeris yang wujud dalam iklan versi terjemahan. Selain itu, kajian keinggerisan dalam iklan pernah dilakukan oleh Smith (2002) di Rusia. Dalam kajiannya yang berfokuskan penterjemahan tajuk utama dalam iklan bercetak, Smith mendapati iklan di Rusia masih terikat dengan gaya iklan berbahasa Inggeris. Penterjemah iklan di Rusia juga cenderung untuk meminjam perkataan bahasa Inggeris dan cenderung membuat andaian bahawa khalayak Rusia memahami bahasa Inggeris.

Selain itu, Basem (2006) menghujahkan prosedur terjemahan merupakan penyebab keinggerisan berlaku dalam terjemahan menu makanan segera. Prosedur peminjaman dan transliterasi dihujahkan sebagai penyebab responden kajian yang tidak mahir berbahasa Inggeris menghadapi kesukaran untuk memahami menu. Misalnya perkataan nugget dalam bahasa Inggeris dipinjam dan ditulis semula secara transliterasi dalam bahasa Arab. Walaupun bahasa Arab digunakan, pembaca masih tidak mendapat maklumat rasa, kandungan, bentuk dan warna makanan kerana konsep nugget wujud di Barat dan tidak berasal daripada budaya Arab. Situasi yang sama juga berlaku dalam penterjemahan perkataan hamburger dan hot dog yang membawa konotasi negatif dan kurang sesuai dengan budaya masyarakat Arab.

Terdapat pelbagai prosedur terjemahan, namun kajian Basem (2006) secara khusus mengaitkan prosedur peminjaman dengan keinggerisan dalam kajian beliau. Prosedur terjemahan digunakan untuk menterjemah ayat dan unit bahasa yang lebih kecil seperti klausa dan perkataan. Peminjaman (transference) merujuk kepada pemindahan perkataan daripada teks sumber ke dalam teks sasaran. Perkataan ini dikenali sebagai perkataan pinjaman disebabkan oleh bentuk asal perkataan dikekalkan dalam bahasa sasaran, misalnya perkataan yang tiada padanan dalam bahasa sasaran seperti nama tempat, nama penyakit dan judul akhbar. Selain itu, terdapat pemindahan perkataan daripada teks sumber ke dalam teks sasaran yang melibatkan penyesuaian daripada segi ejaan dan sebutan. Prosedur terjemahan ini dikenali sebagai prosedur naturalisasi (naturalisation), misalnya perkataan scrub diterjemahkan menjadi "skrub" (Newmark 1988). 
Peminjaman perkataan atau istilah asing bukan fenomena baharu dalam bahasa Melayu. Pedoman Umum Pembentukan Istilah Bahasa Melayu (PUPIBM 2004) misalnya menggariskan lima kaedah penyerapan istilah asing menjadi istilah Melayu. Pertama, penyerapan berlaku apabila istilah asing yang diserap memperlihatkan mudahnya pemindahan timbal balik antara istilah asing dengan istilah Melayu. Kedua, penyerapan istilah asing memudahkan pemahaman teks asing oleh pembaca di Malaysia. Ketiga, istilah asing yang diserap lebih ringkas jika dibandingkan dengan terjemahan bahasa Melayu. Keempat, istilah asing yang diserap mempermudahkan kesepakatan antara pakar jika padanan terjemahan mempunyai terlalu banyak sinonim, dan yang kelima, istilah asing yang diserap tidak mengandungi konotasi negatif.

Kajian lampau menunjukkan permasalahan tentang isu keinggerisan, khususnya kata pinjaman bahasa Inggeris yang berlaku dalam penterjemahan iklan di Malaysia mahupun luar negara. Selain itu, kajian keinggerisan juga mencakupi pelbagai isu seperti bahasa (Mohd. Sidin dan Noorbathi 1993), semiotik (Maserah dan Idris 2012), penterjemahan (Asmah 1984; Newmark 1988; Haslina 2006) dan kesan keinggerisan (Basem 2006; Fischer 2008). Walau bagaimanapun, makalah ini hanya menumpukan kepada kata pinjaman bahasa Inggeris yang wujud dalam katalog berbahasa Melayu versi terjemahan serta kesannya daripada perspektif penterjemahan.

\section{Objektif Kajian}

Objektif kajian yang dilakukan ini adalah seperti berikut:

1. Mengenal pasti dan mengelaskan kategori kata pinjaman bahasa Inggeris yang wujud dalam terjemahan tajuk utama iklan bagi katalog bercetak Cosway dan Avon.

2. Menghuraikan kesan peminjaman perkataan bahasa Inggeris yang wujud dalam terjemahan tajuk utama iklan bagi katalog bercetak Cosway dan Avon.

\section{Persoalan Kajian}

Bagi mencapai objektif kajian, persoalan kajian dibina seperti berikut:

1. Apakah kategori kata pinjaman bahasa Inggeris yang wujud dalam terjemahan tajuk utama iklan bagi katalog bercetak Cosway dan Avon?

2. Apakah kesan peminjaman perkataan bahasa Inggeris yang wujud dalam terjemahan tajuk utama iklan bagi katalog bercetak Cosway dan Avon? 


\section{Data Kajian}

Katalog bercetak dipilih sebagai data kajian kerana ia merupakan bahan sedia ada dalam persekitaran kehidupan harian dan tidak direka bagi tujuan penyelidikan. Selain itu, katalog bercetak merupakan rekod tetap yang bersifat tahan lama, mempunyai pembaca yang khusus dan memenuhi keperluan sesetengah pengiklan. Walaupun perkembangan teknologi menyebabkan kemunculan medium elektronik, faktor permintaan jelas memastikan kemandirian medium bercetak. Misalnya, syarikat jualan langsung seperti Cosway dan Avon menggunakan katalog bercetak bagi menyampaikan maklumat produk kepada ahli berdaftar berbanding mengiklankan produk dalam televisyen atau radio.

Syarikat Cosway memulakan operasi pada tahun 1979 berlandaskan konsep pemasaran produk berkualiti pada harga kompetitif. Cosway juga merupakan anak syarikat kepada Berjaya Goup, iaitu konglomerat multinasional yang terkenal disebabkan oleh kepelbagaian pasarannya. Syarikat Avon pula merupakan syarikat yang sinonim dengan slogannya yang khusus buat wanita, iaitu "The company for women". Dalam konteks kajian ini, katalog bercetak Cosway dan Avon memainkan peranan penting selaku perantara antara syarikat serta orang awam yang melanggan dengannya. Melalui katalog ini, pelanggan mendapat maklumat produk serta diskaun yang diberikan terhadap produk terpilih sewaktu tempoh promosi diadakan.

Data kajian dikumpulkan selama tiga bulan, iaitu dari Ogos 2013 hingga Oktober 2013. Terdapat enam katalog Avon dan tiga katalog Cosway yang dikumpulkan. Keseluruhannya, terdapat 1,032 tajuk utama versi bahasa Inggeris dan 1,032 tajuk utama versi bahasa Melayu yang digunakan sebagai data kajian. Faktor pemilihan kedua-dua katalog berkenaan sebagai medium kajian adalah disebabkan oleh maklumat boleh dicapai dalam dwibahasa. Kajian ini merupakan kajian penterjemahan, maka iklan dwibahasa perlu digunakan bagi membolehkan analisis perbandingan antara teks dilakukan. Selain itu, bilangan tajuk utama yang tinggi dalam katalog Cosway dan Avon membawa implikasi bahawa syarikat Cosway dan Avon menekankan kepentingan tajuk utama dalam mempromosikan produk.

Katalog bercetak terdiri daripada komponen tajuk utama, tajuk kecil, tubuh iklan, slogan, ilustrasi, logo dan penutup. Komponen iklan yang dikaji dalam kajian ini ialah tajuk utama atau padanan dalam bahasa Inggerisnya ialah headline. Penekanan diberikan pada penterjemahan tajuk utama kerana tajuk utama merupakan bahagian terpenting iklan dan merupakan perkara pertama yang menarik perhatian bakal pembeli produk (Asmah 1984; Bolen 1984). Selain itu, Mohd. Sidin Ahmad dan Noorbathi (1993) menyatakan dapatan kajian terdahulu membuktikan khalayak 
cenderung membaca tajuk utama sahaja. Rata-rata pembaca dinyatakan membelek halaman demi halaman dalam masa yang singkat, justeru terdapat kebarangkalian bahawa hanya tajuk utama yang sempat dibaca oleh pembaca.

Tambahan pula, penterjemahan tajuk utama sesuai dikaji bagi meneliti aspek kata pinjaman bahasa Inggeris. Tajuk utama bersifat memberi maklumat dan pemujukan. Bagi mencapai tujuan memaklumkan serta memujuk pembaca agar membeli produk, para pengiklan menggunakan bahasa tertentu yang sinonim dengan laras bahasa iklan (Torresi 2010). Misalnya nama dan keterangan produk yang terkandung dalam tajuk utama mengandungi pun, artikel the (definite article), jargon dan neologisme. Data yang menarik ini membolehkan penulis mengenal pasti serta mengelaskan kategori kata pinjaman yang wujud dalam katalog kajian.

\section{Pelabelan data kajian}

Tajuk utama katalog bercetak Cosway dan Avon dilabel bagi memudahkan sumber katalog dibezakan. Awalan C1 digunakan bagi katalog Cosway yang pertama, diikuti dengan $\mathrm{C} 2$ bagi katalog kedua dan $\mathrm{C} 3$ bagi katalog ketiga. Tajuk utama dalam katalog Cosway pula dilabel D1 hingga seterusnya, iaitu meliputi bilangan data yang diperoleh dalam katalog. Sewaktu analisis data, gabungan label C1D1 digunakan bagi merujuk kepada katalog Cosway satu dan data satu, seterusnya disusuli dengan label C1D2 sehingga label terakhir, iaitu C3D200. Sistem label yang sama digunakan bagi katalog Avon. Iklan bahasa Inggeris dilabel sebagai teks selari I (TS I) dan iklan bahasa Melayu dilabel sebagai teks selari II (TS II). Rasional bagi pemilihan istilah ini ialah istilah teks selari sering digunakan dalam penterjemahan iklan berbanding istilah teks sumber dan teks sasaran (Torresi 2010). Hal ini disebabkan oleh wujud ketidakpastian sama ada teks asal ditulis dalam versi bahasa Melayu, bahasa Inggeris atau kedua-duanya ditulis secara serentak.

\section{Kerangka Pendekatan}

Kata pinjaman terhasil menerusi peminjaman perkataan dan istilah daripada sesuatu bahasa kepada bahasa-bahasa lain. Dalam konteks kajian ini, hanya kata pinjaman bahasa Inggeris yang dikutip dalam katalog bercetak versi terjemahan yang dikaji. Menurut Haugen (1972), terdapat tiga kategori kata pinjaman, namun hanya kategori pertama, iaitu kata pinjaman (loanwords) sahaja yang akan dihuraikan dalam makalah ini. Bagi memudahkan proses mengenal pasti dan menganalisis data, penulis memanfaatkan definisi kata pinjaman oleh Haugen ini, iaitu kata pinjaman merupakan pengimportan morfem dan pemindahan terus leksem daripada segi bentuk dan makna. Perkataan ini dikenali sebagai "kata pinjaman" disebabkan oleh bentuk asal perkataan dikekalkan. 
Kategori kata pinjaman kedua ialah kata pinjaman gabungan (loanblends) yang juga dikenali sebagai pseudo Anglicisms dan hybrid Anglicisms. Kategori kedua terhasil menerusi gabungan peminjaman bentuk dan penggantian elemen asal yang menghasilkan hibrid antara bahasa asing dengan bahasa penerima. Dalam erti kata lain, kata pinjaman ini terhasil menerusi gabungan komponen perkataan asing dan perkataan asal dalam bahasa Melayu. Misalnya, awalan asing pro- yang bermaksud menyokong apabila digabungkan dengan perkataan "pembangkang" (bahasa Melayu) akan menjadi "propembangkang” (menyokong pihak pembangkang).

Kategori pinjaman ketiga ialah pinjam ubah (loanshifts) yang terhasil menerusi peminjaman konsep perkataan dalam bahasa asal lalu dikembangkan maksud dan konsepnya dalam bahasa sasaran. Pinjam ubah ini merupakan peminjaman kata atau frasa daripada satu bahasa yang melibatkan pengubahsuaian serentak bentuk fonologi seperti bungalow (bahasa Inggeris) kepada "banglo" dalam bahasa Melayu (Kamus Linguistik 1997, 191). Kategori ketiga ini dikenali juga sebagai pengembangan semantik. Misalnya, konsep perkataan terror (gentar atau ketakutan) dalam bahasa Inggeris dikembangkan maksudnya dalam bahasa Melayu menjadi "terer" yang merujuk kepada makna hebat dan pintar. Ringkasan bagi ketiga-tiga kategori kata pinjaman Haugen ini diringkaskan seperti dalam Rajah 1.

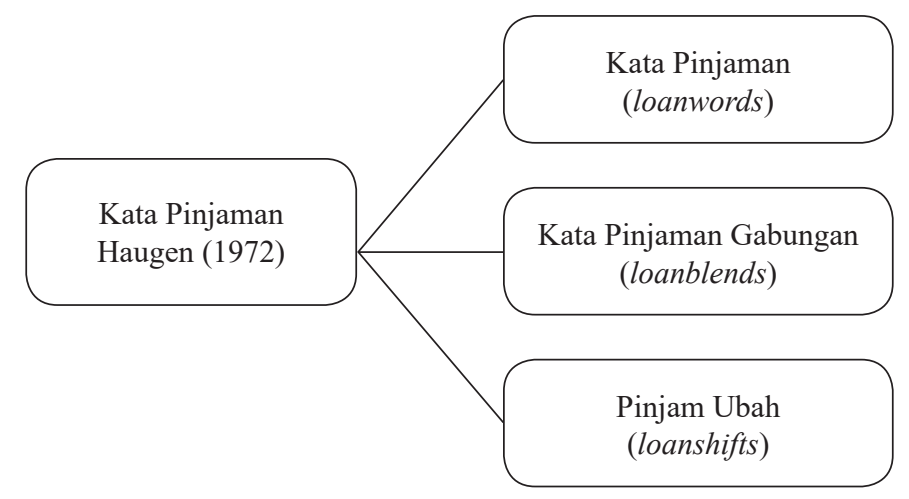

Rajah 1. Ringkasan tiga kategori kata pinjaman Haugen (1972)

Terdapat perkaitan antara prosedur terjemahan Newmark (1988), kategori kata pinjaman Haugen (1972) dan kaedah penyerapan yang digariskan dalam PUPIBM (2004). Perkaitan berkenaan diringkaskan dalam Jadual 1.

Ringkasan ini memperlihatkan perkaitan antara prosedur terjemahan yang sinonim dengan bidang terjemahan, perkataan pinjaman bahasa Inggeris yang digunakan bagi mencirikan unsur keinggerisan serta pedoman umum pembentukan istilah yang diaplikasikan oleh pakar peristilahan bahasa Melayu. Walaupun istilah yang 
berbeza digunakan, wujud persamaan daripada segi aplikasi dan pembahagiannya. Daripada segi konteks penterjemahan, prosedur terjemahan tidak terhad pada peringkat penterjemahan perkataan sahaja. Newmark (1988) menyenaraikan prosedur terjemahan seperti prosedur parafrasa, persamaan deskriptif dan sebagainya yang sesuai diaplikasikan bagi menterjemahkan ayat. Oleh sebab bahasa sasaran merupakan bahasa Melayu, cara pembentukan istilah dan ejaan dalam bahasa Melayu perlu dipertimbangkan dengan merujuk kepada Pedoman Umum Pembentukan Istilah Bahasa Melayu (PUPIBM 2004) dan Pedoman Umum Ejaan Bahasa Melayu (PUEBM 1992).

Jadual 1. Perkaitan antara prosedur terjemahan, kategori kata pinjaman dan pembentukan istilah bahasa Melayu

\begin{tabular}{|c|c|c|}
\hline Newmark (1988) & Haugen (1972) & PUPIBM (2004) \\
\hline $\begin{array}{l}\text { Prosedur peminjaman } \\
\text { (transference) } \\
\text { - Perkataan dipinjam tanpa } \\
\text { perubahan ejaan. }\end{array}$ & $\begin{array}{l}\text { Kata pinjaman (loanword) } \\
\text { - Perkataan dipinjam dengan } \\
\text { perubahan ejaan atau tanpa } \\
\text { perubahan ejaan. }\end{array}$ & $\begin{array}{l}\text { Penyerapan istilah dengan } \\
\text { perubahan ejaan atau tanpa } \\
\text { perubahan ejaan. }\end{array}$ \\
\hline $\begin{array}{l}\text { Prosedur naturalisasi } \\
\text { (naturalisation) } \\
\text { - Perkataan dipinjam dengan } \\
\text { perubahan ejaan. }\end{array}$ & $\begin{array}{l}\text { Kata pinjaman gabungan } \\
\text { (loanblend }) \\
\text { - Perkataan bahasa sumber } \\
\text { dipinjam dan digabungkan } \\
\text { dengan perkataan dalam } \\
\text { bahasa sasaran. }\end{array}$ & $\begin{array}{l}\text { Pembentukan kata terbitan } \\
\text { dengan imbuhan asing dan } \\
\text { bentuk gabungan. }\end{array}$ \\
\hline
\end{tabular}

Penulis memanfaatkan pandangan Heah (1989) dan Puteri Roslina (2012) sewaktu menganalisis data kata pinjaman. Pandangan kedua-dua sarjana tersebut dimanfaatkan bagi membina perincian bagi kata pinjaman (KP) yang dibahagikan kepada kata pinjaman tidak asimilasi (KPTA), kata pinjaman separa asimilasi (KPSA), kata pinjaman asimilasi lengkap (KPAL), kata pinjaman asimilasi ortografi (KPAO), kata pinjaman majmuk asimilasi (KPMA), kata pinjaman majmuk cantum (KPMC) dan kata pinjaman asing yang dipendekkan (KPAP). Ringkasan dan keterangan bagi kesemua kategori kata pinjaman ini adalah seperti dalam Jadual 2.

\section{Dapatan Kajian dan Perbincangan}

Berdasarkan analisis data, bilangan bagi setiap perincian kata pinjaman dikelaskan seperti dalam Jadual 3. Analisis bagi setiap kategori akan dibincangkan, namun tidak kesemua 2,064 tajuk utama dibincangkan analisisnya dalam makalah ini. Beberapa data yang signifikan sahaja yang dipilih bagi mewakili keseluruhan data. 
Jadual 2. Perincian kata pinjaman

\begin{tabular}{|c|c|c|c|}
\hline Kategori & Perincian & Keterangan & Contoh \\
\hline \multirow[t]{7}{*}{ KP } & KPTA & $\begin{array}{l}\text { Kata pinjaman yang diambil secara } \\
\text { keseluruhan. }\end{array}$ & analog $\rightarrow$ analog \\
\hline & KPSA & $\begin{array}{l}\text { Kata pinjaman yang mengalami penyesuaian } \\
\text { ortografi tetapi terdapat unsur yang } \\
\text { menunjukkan ciri bahasa asing. Kata pinjaman } \\
\text { ini belum sebati dalam bahasa sasaran daripada } \\
\text { segi sebutan dan ejaan. }\end{array}$ & script $\rightarrow$ skrip \\
\hline & KPAL & $\begin{array}{l}\text { Kata pinjaman yang terhasil menerusi } \\
\text { penyesuaian ortografi dan sukar dikenal pasti } \\
\text { asalnya kerana telah diasimilasikan dalam } \\
\text { budaya Melayu. }\end{array}$ & pension $\rightarrow$ pencen \\
\hline & KPAO & $\begin{array}{l}\text { Kata pinjaman yang disesuaikan ejaannya } \\
\text { dalam bahasa Melayu tetapi sebutannya masih } \\
\text { sama dengan sebutan bahasa asing. }\end{array}$ & squash $\rightarrow$ skuasy \\
\hline & KPMA & $\begin{array}{l}\text { Kata majmuk yang dipinjam dan disesuaikan } \\
\text { dengan pola sintaktik dalam bahasa Melayu. }\end{array}$ & $\begin{array}{l}\text { capitulation treaty } \rightarrow \\
\text { triti kapitulasi }\end{array}$ \\
\hline & KPMC & $\begin{array}{l}\text { Kata majmuk yang diserap ke dalam bahasa } \\
\text { Melayu sebagai satu unit dan mengalami } \\
\text { kehilangan identiti dwimorfemik. }\end{array}$ & lock-up $\rightarrow$ lokap \\
\hline & KPAP & $\begin{array}{l}\text { Kata pinjaman yang wujud akibat kata } \\
\text { pinjaman yang mempunyai lebih daripada } \\
\text { dua suku kata yang dipendekkan atau disusun } \\
\text { semula. }\end{array}$ & principle $\rightarrow$ prinsip \\
\hline
\end{tabular}

Sumber: Dipetik dan diubah suai daripada Heah (1989) dan Puteri Roslina (2012)

Jadual 3. Bilangan kata pinjaman dalam katalog bercetak Cosway dan Avon

\begin{tabular}{llccc}
\hline Kategori & Perincian & Cosway & Avon & Jumlah \\
\hline KP & KPTA & 168 & 75 & 243 \\
& KPSA & 15 & 6 & 21 \\
& KPAL & 5 & 4 & 9 \\
& KPAO & 20 & 5 & 25 \\
KPMA & 5 & 2 & 7 \\
& KPMC & 0 & 0 & 0 \\
KPAP & 1 & 0 & 1 \\
\hline
\end{tabular}




\section{Kata Pinjaman Tidak Asimilasi (KPTA)}

Kategori pertama ialah KPTA, iaitu kata pinjaman yang diambil secara keseluruhan. Bagi kata pinjaman jenis ini, penterjemah hanya meminjam perkataan asing tanpa melibatkan sebarang pengubahsuaian ejaan atau perubahan makna.

$\begin{array}{ll}\text { Data } & \text { Teks Selari I } \\ \text { C1D9 } & \text { Echinacea: Super Charge } \\ & \text { Your Immune Defences } \\ \text { A4D55 } & \underline{\text { BPA Free, Multi-Purpose Bottles }}\end{array}$

\author{
Teks Selari II \\ Echinacea: Memperkuatkan \\ Sistem Imun Badan Anda \\ Botol Pelbagai Guna yang Bebas BPA
}

Data C1D9 menunjukkan perkataan echinacea dipinjam ke dalam tajuk utama berbahasa Melayu. Istilah ini merujuk kepada produk kapsul echinacea yang berperanan menentang batuk dan selesema serta melindungi penggunanya daripada jangkitan virus. Penterjemah sekadar meminjam atau menyalin semula ejaan bagi istilah berkenaan ke dalam bahasa Melayu. Bagi data A4D55, penterjemah meminjam akronim BPA ke dalam bahasa Melayu. Akronim ialah kata tunggal yang terbentuk daripada huruf-huruf pertama, suku kata atau bahagian daripada perkataan lain (Nathesan 2015). Dalam contoh ini, akronim BPA merujuk kepada Bisphenol A, iaitu bahan kimia industri yang digunakan dalam pembuatan barangan plastik. Penterjemah sekadar meminjam akronim BPA ke dalam TS II tanpa sebarang pengubahsuaian ejaan dan penterjemah tidak memperincikan makna bagi setiap perkataan yang membentuk akronim BPA. Faktor gaya penulisan tajuk utama yang ringkas dan kreatif menyebabkan penterjemah tidak menambah maklumat atau nota kaki bagi menjelaskan maksud istilah atau akronim dalam iklan.

$\begin{array}{ll}\text { Data } & \text { Teks Selari I } \\ \text { A6D1 } & \begin{array}{l}\text { Your favourite Sweet Honesty } \\ \text { scents, all in one special pack! }\end{array}\end{array}$

\section{Teks Selari II}

Rangkaian Sweet Honesty kegemaran anda, kini di dalam satu pek istimewa!

Penterjemah mengekalkan atau meminjam nama produk, iaitu nama jenama Sweet Honesty (data A6D1) yang tidak diterjemahkan dan hanya dipinjam. Selain itu, tiada perubahan ejaan yang berlaku dalam pengejaan nama produk tempatan mahupun antarabangsa. Dapatan ini selaras dengan pandangan Ismail (1997) yang menyatakan produk antarabangsa boleh mengekalkan nama asing, dan tidak perlu menterjemah nama bagi sesuatu jenama ke dalam bahasa Melayu. Ringkasan bagi kategori perkataan yang dipinjam ke dalam bahasa Melayu tanpa sebarang perubahan ejaan adalah seperti dalam Jadual 4. 
Jadual 4. Kategori KPTA dalam tajuk utama

\begin{tabular}{ll}
\hline Kategori & \multicolumn{1}{c}{ Keterangan } \\
\hline $\begin{array}{l}\text { Istilah bidang } \\
\text { dan akronim }\end{array}$ & $\begin{array}{l}\text { Penterjemah meminjam istilah dan akronim disebabkan oleh faktor istilah } \\
\text { yang diserap memperlihatkan mudahnya pemindahan timbal balik antara } \\
\text { istilah asing dengan istilah Melayu, memudahkan pemahaman teks asing } \\
\text { oleh pembaca Malaysia, dan istilah asing yang diserap lebih ringkas jika } \\
\text { dibandingkan dengan terjemahan dalam bahasa Melayu. }\end{array}$ \\
& $\begin{array}{l}\text { Penterjemah meminjam nama makanan dan tumbuhan yang sinonim dengan } \\
\text { Nama makanan } \\
\text { dan tumbuhan }\end{array}$ \\
& $\begin{array}{l}\text { Produk tempatan yang menggunakan bahan herba seperti tongkat ali, gamat, } \\
\text { kacip fatimah dan manjakani masih mengekalkan perkataan berkenaan } \\
\text { dengan ejaannya yang asal walaupun ditulis dalam tajuk utama berbahasa }\end{array}$ \\
& $\begin{array}{l}\text { Inggeris. } \\
\text { Nama jenama }\end{array}$ \\
& $\begin{array}{l}\text { Penterjemah meminjam nama produk antarabangsa seperti Stock Pot dan } \\
\text { Sweet Honesty ke dalam TS II. Hal ini disebabkan oleh produk antarabangsa } \\
\text { boleh mengekalkan nama asing dan tidak perlu menterjemah nama bagi } \\
\text { sesuatu jenama ke dalam bahasa Melayu. }\end{array}$ \\
\hline
\end{tabular}

\section{Kata Pinjaman Separa Asimilasi (KPSA)}

Kategori kedua ialah KPSA, iaitu kata pinjaman yang mengalami penyesuaian ortografi (sistem ejaan) tetapi terdapat unsur yang menunjukkan ciri bahasa asing. Kata pinjaman jenis ini belum sebati dalam bahasa sasaran daripada segi sebutan dan ejaan. Pengejaan istilah pula dilakukan dengan mengubah unsur yang perlu sahaja supaya bentuk asal masih kelihatan. Langkah ini diambil bagi memudahkan pengenalan istilah baharu untuk dibandingkan dengan istilah asal dalam bahasa sumber. Puteri Roslina (2012) menjelaskan ciri yang ketara dalam bahasa Melayu ialah tiada gugusan konsonan seperti fl, tl, pr, tr, sk, pl dan st pada awal, tengah dan akhir kata. Selain gugusan konsonan yang disenaraikan, penulis turut merujuk Pedoman Umum Ejaan Bahasa Melayu (PUEBM 1992) bagi tujuan menganalisis data daripada aspek ejaan.

$\begin{array}{ll}\text { Data } & \text { Teks Selari I } \\ \text { C2D28 } & \begin{array}{l}\text { Energy Pendant for Better } \\ \text { Circulation, Energy, } \text { Flexibility } \\ \text { \& Strength }\end{array} \\ & \begin{array}{l}\text { Deep cleanse pores in ONE } \\ \text { AASY } \underline{\text { SCRUB! }}\end{array} \\ \text { A1D56 } & \begin{array}{l}\text { M-frame bra ... stability } \\ \text { without wires }\end{array}\end{array}$

\section{Teks Selari II}

Loket Tenaga untuk Peredaran yang Lebih Lancar, Tenaga,

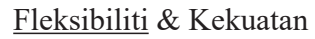

Bersihkan liang dengan mendalam DENGAN SATU SKRUB!

Coli berbingkai M ... stabiliti tanpa dawai 
Data C2D28 menunjukkan perkataan flexibility dipinjam ke dalam TS II menerusi penyesuaian ejaan -ex- menjadi -eks- dan -ty menjadi -ti. Konsonan fl- bagi perkataan "fleksibiliti" dalam TS II memberikan maklumat bahawa perkataan ini mengandungi ciri asing. Hal ini disebabkan oleh bahasa Melayu tidak mempunyai gugusan konsonan fl- di bahagian awal kata. Tambahan pula, wujud perkataan sinonim bagi fleksibiliti dalam bahasa Melayu seperti perkataan "luwes" dan "boleh diubah atau disesuaikan" (Kamus Dewan Edisi Keempat 2007, 413). Data A1D30 menunjukkan penyesuaian yang berlaku dalam ejaan perkataan apabila huruf $s c$ - menjadi sk-. Kehadiran gugusan konsonan sk- memberikan maklumat bahawa perkataan "skrub" wujud menerusi peminjaman perkataan asing. Perkataan ini sering digunakan dalam konteks kecantikan seperti skrub badan dan skrub muka berbanding perkataan yang sedia ada dalam bahasa Melayu seperti "lulur" badan. Berbanding kata "skrub" yang tidak disenaraikan sebagai kata masukan Kamus Dewan Edisi Keempat, kata "stabiliti" ditakrifkan sebagai keadaan stabil atau kemantapan (Kamus Dewan Edisi Keempat 2007, 1522). Perkataan stabiliti dalam data A1D56 juga dikenal pasti sebagai kata pinjaman menerusi kehadiran konsonan st- yang digunakan dalam ejaan. Analisis data KPSA memberikan maklumat bahawa penterjemah katalog bercetak Cosway dan Avon cenderung meminjam perkataan bahasa Inggeris dan menyesuaikan ejaannya dengan ejaan bahasa Melayu, walaupun perkataan tersebut mempunyai padanan terjemahan dalam bahasa Melayu.

\section{Kata Pinjaman Asimilasi Lengkap (KPAL)}

Kategori ketiga ialah KPAL, iaitu kata pinjaman yang terhasil menerusi penyesuaian ortografi dan sukar untuk dikenal pasti asalnya kerana telah diasimilasikan dalam budaya Melayu. Puteri Roslina (2012) menjelaskan KPAL sukar dikenal pasti kecuali seseorang itu mengetahui latar budaya dan sejarah yang membawa kepada pertembungan bahasa yang terlibat.

Analisis menunjukkan penggunaan perkataan pinjaman secara kerap mampu mempengaruhi penerimaannya dalam bahasa Melayu. Data C1D191 dan C2D160 misalnya mengandungi kata asing "enjin" dan "mesin" yang pengucapan dan penulisannya sudah sebati dalam bahasa Melayu. Heah (1989) menyenaraikan kata "enjin" dan "mesin" sebagai kategori KPAL dalam kajiannya yang terdahulu. Data A1D66 pula menunjukkan perkataan products (plural) yang diterjemahkan menjadi perkataan "produk" dalam bahasa Melayu. Perkataan produk juga sudah sebati dalam bahasa Melayu dan digunakan dalam pelbagai konteks, seperti produk alat solek, produk kesihatan, produk bagi sesuatu kajian saintifik, produk dalam industri perkhidmatan, periklanan dan sebagainya. Tambahan pula, perkataan produk cenderung digunakan dalam konteks bahasa Melayu sehingga tersenarai 
sebagai kata masukan dalam Kamus Dewan Edisi Keempat $(2007,1232)$ walaupun mempunyai perkataan sinonim, iaitu perkataan "barangan" dalam konteks bahasa Melayu.

$\begin{array}{lll}\text { Data } & \text { Teks Selari I } & \text { Teks Selari II } \\ \text { C1D191 } & \begin{array}{l}\text { 'Balik Kampung'with Roadmaster, } \\ \text { The Ultimate Engine Oil }\end{array} & \begin{array}{l}\text { 'Balik Kampung' dengan } \\ \text { Roadmaster, Minyak Enjin } \\ \text { yang Terunggul }\end{array} \\ \text { C2D160 } & \begin{array}{l}\text { Cleans \& Sanitises Washing } \\ \text { Machine }\end{array} & \begin{array}{l}\text { Membersih \& Menyahkuman } \\ \text { Mesin Pembasuh }\end{array} \\ \text { A1D66 } & \text { “Feels even better than other } & \begin{array}{l}\text { "Terasa lebih hebat dari produk } \\ \text { pembentuk lain!” }\end{array} \\ & \text { shaping products!” } & \text { Kuasa Teknologi Penindas } \\ \text { A3D37 } & \begin{array}{l}\text { DOUBLE THE STRENGTH of } \\ \text { Melanin Captivation Whitening } \\ \text { Technology! }\end{array} & \text { Melanin KINI DIGANDAKAN! }\end{array}$

Data A3D37 menunjukkan perkataan "teknologi" yang lazim digunakan dalam bahasa Melayu. Ledakan teknologi telah menyebabkan perkataan seperti teknologi maklumat, teknologi hijau dan sebagainya sering digunakan dalam konteks bahasa Melayu dan tidak wujud padanan terjemahan yang lebih ringkas dalam bahasa Melayu bagi menggambarkan maksud perkataan teknologi. Penggunaan keterangan bagi perkataan teknologi, iaitu aktiviti atau kajian yang menggunakan pengetahuan sains untuk tujuan praktis dalam industri, pertanian, perubatan dan sebagainya (Kamus Dewan Edisi Keempat 2007, 1630) jelas kurang sesuai digunakan dalam medium periklanan yang mengutamakan penggunaan perkataan terhad tetapi mempunyai kesan yang mendalam. Oleh itu, analisis data memberikan maklumat bahawa penterjemah menggunakan KPAL dalam penulisan tajuk utama disebabkan oleh faktor kata asing berkenaan telah sebati dalam bahasa Melayu.

\section{Kata Pinjaman Asimilasi Ortografi (KPAO)}

Kategori keempat ialah KPAO, iaitu kata pinjaman yang disesuaikan ejaannya dalam bahasa Melayu tetapi sebutannya masih sama dengan sebutan bahasa asing. Puteri Roslina (2012) memerihalkan bahawa perbezaan ketara antara KPAO dengan bahasa sumber boleh dikenal pasti melalui bentuk ortografi. Hal ini disebabkan oleh ortografi dalam bahasa Inggeris tidak fonemik berbanding bentuk ortografi dalam bahasa Melayu yang bersifat fonemik. Oleh itu, ejaan dalam bahasa sumber dipertahankan dalam bahasa Melayu dengan perubahan fonem dan/ atau pengguguran huruf dilakukan apabila diperlukan sahaja.

Terdapat data dalam katalog kajian yang ejaannya disesuaikan dalam bahasa Melayu tetapi sebutannya masih sama dengan sebutan bahasa asing. Perkataan 
seperti tradisional, virus, bakteria, diet, syampu, losen dan fesyen masih mengekalkan sebutan asal dalam bahasa Inggeris. Hal ini disebabkan oleh PUEBM (1992) menggariskan bahawa bagi mengeja istilah atau perkataan pinjaman, yang dipentingkan dalam istilah dan perkataan ialah bentuk ejaan (visualnya) dan bukannya lafaz atau bunyi. Penulis juga mendapati penterjemah melakukan kesalahan sewaktu mengeja kata asing, misalnya ejaan perkataan "losyen" yang betul ialah "losen". Kamus Dewan Edisi Keempat (2007) menggunakan ejaan losen sebagai kata masukan dengan perincian makna cecair yang disapukan pada kulit. Bagi kata pinjaman kategori KPAO, wujud kekeliruan sewaktu mengeja perkataan dalam bahasa Melayu. Analisis data KPAO memberikan maklumat tambahan bahawa faktor sebutan perkataan pinjaman yang cenderung ke arah bahasa Inggeris menyebabkan penterjemah melakukan kesalahan ejaan perkataan dalam bahasa Melayu.

\begin{tabular}{|c|c|c|}
\hline Data & Teks Selari I & Teks Selari II \\
\hline C1D17 & $\begin{array}{l}\text { A Traditional Japanese Remedy } \\
\text { for Over } 100 \text { Kinds of Illnesses }\end{array}$ & $\begin{array}{l}\text { Penawar Tradisional Masyarakat } \\
\text { Jepun untuk Lebih daripada } 100 \\
\text { Jenis Penyakit }\end{array}$ \\
\hline C2D154 & $\begin{array}{l}\text { Kill Viruses } \& \text { Bacteria } \\
\text { Effectively! }\end{array}$ & $\begin{array}{l}\text { Berkesan Membunuh Virus \& } \\
\text { Bakteria! }\end{array}$ \\
\hline C3D51 & $\begin{array}{l}\text { Lose More Weight with } \\
\text { Auriculotherapy Without } \\
\text { Starvation, Diet Pills, or Exercise }\end{array}$ & $\begin{array}{l}\text { Kurangkan Lebih Banyak Berat } \\
\text { Badan dengan Aurikuloterapi } \\
\text { Tanpa Kelaparan, Pil Diet, atau } \\
\text { Senaman }\end{array}$ \\
\hline C1D143 & $\begin{array}{l}8 \text { Minutes Shampoo-On-Colourant } \\
\text { for Perfect Grey Coverage }\end{array}$ & $\begin{array}{l}8 \text { Minit Pewarna Syampu untuk } \\
\text { Penutupan Uban Sempurna }\end{array}$ \\
\hline C3D92 & $\begin{array}{l}\text { Protective Lotion Keeps } \\
\text { Mosquitoes Away }\end{array}$ & $\begin{array}{l}\text { Losyen Perlindungan yang } \\
\text { Menjauhkan Nyamuk }\end{array}$ \\
\hline A1D67 & Gentle Fashion for Young Female & Pesona Fesyen Wanita Muda \\
\hline
\end{tabular}

\section{Kata Pinjaman Majmuk Asimilasi (KPMA)}

Kategori kelima ialah KPMA, iaitu kata majmuk yang dipinjam dan disesuaikan dengan pola sintaktik dalam bahasa Melayu. Puteri Roslina (2012) menjelaskan asimilasi morfosintaktik berlaku apabila perkataan dalam bahasa Inggeris disesuaikan sebagai satu unit analisis, dan susunan morfosintaktik bahasa Inggeris disesuaikan dengan sintaksis bahasa Melayu.

Analisis menunjukkan wujud kata majmuk yang dipinjam daripada bahasa Inggeris dan penulisannya disesuaikan dengan pola sintaksis bahasa Melayu. Bagi data C1D64, penterjemah menterjemahkan perkataan acid menjadi "asid" 
dan hyaluronic menjadi "hialuronik". Penyesuaian ejaan dilakukan berdasarkan panduan ejaan dalam PUEBM (1992), misalnya hya- menjadi hia- dan -nic menjadi -nik. Seterusnya susunan perkataan diubah bagi disesuaikan dengan hukum DM dalam bahasa Melayu, iaitu asid sebagai diterangkan dan hialuronik sebagai menerangkan. Hukum DM ialah peraturan penyusunan kata nama majmuk yang mendahulukan unsur yang diterangkan (diringkaskan sebagai D) dan seterusnya kata sifat yang menerangkan (diringkaskan sebagai $M$ ). Langkah yang sama juga diambil bagi menterjemahkan perkataan acid citric dalam data C3D180 dan acid hydrochloric dalam data C2D184. Penterjemah menterjemahkan perkataan acid menjadi "asid" dan citric diterjemahkan menjadi "sitrik", manakala hydrochloric diterjemahkan menjadi "hidroklorik". Analisis data KPMA jelas membuktikan peminjaman perkataan asing dan proses penterjemahan masih terikat dengan hukum tatabahasa bahasa Melayu, misalnya hukum DM. Secara tidak langsung, pertambahan bilangan kata pinjaman bahasa Inggeris sebenarnya tidak memberi kesan terhadap hukum tatabahasa bahasa Melayu.

$\begin{array}{lll}\text { Data } & \text { Teks Selari I } & \text { Teks Selari II } \\ \text { C1D64 } & \begin{array}{l}\text { Recapture the Essence of Youth } \\ \text { with } \underline{\text { Hyaluronic Acid }}\end{array} & \begin{array}{l}\text { Alamilah Esen Keremajaan dengan } \\ \text { Asid Hialuronik }\end{array} \\ \text { C3D180 } & \begin{array}{l}\text { With Pure \& Natural Citric Acid } \\ \text { for Naturally Sparkling Pots }\end{array} & \begin{array}{l}\text { Dengan Asid Sitrik Tulen \& Semula } \\ \text { Jadi untuk Periuk-periuk yang } \\ \text { Bersih Berkilat Secara Semula Jadi }\end{array} \\ \text { C2D184 } & \begin{array}{l}\text { Hydrochloric Acid-free, } \\ \text { Delicious \& Low-Calorie } \\ \text { Premium Seaweed }\end{array} & \begin{array}{l}\text { Rumpai Laut Berkualiti Tinggi } \\ \text { yang Enak, Rendah Kalori \& Tanpa }\end{array} \\ & & \text { Asid Hidroklorik! }\end{array}$

\section{Kata Pinjaman Majmuk Cantum (KPMC)}

Kategori keenam ialah KPMC, iaitu kata majmuk yang diserap ke dalam bahasa Melayu sebagai satu unit dan mengalami kehilangan identiti dwimorfemik. Puteri Roslina (2012) menjelaskan bentuk KPMC lazimnya berlaku secara spontan, misalnya perkataan "lokap" (lock-up) dan "mekap" (make-up). Berdasarkan analisis data, penulis tidak memperoleh sebarang data bagi mewakili KPMC dalam katalog bercetak Cosway dan Avon.

\section{Kata Pinjaman Asing yang Dipendekkan (KPAP)}

Kategori ketujuh ialah KPAP, iaitu kata pinjaman yang wujud akibat kata pinjaman yang mempunyai lebih daripada dua suku kata yang dipendekkan atau disusun semula. Puteri Roslina (2012) menyatakan bentuk KPAP berlaku kerana bahasa Melayu merupakan bahasa yang mempunyai dwisuku kata. Heah (1989) juga 
menjelaskan ciri bahasa Melayu yang menggugurkan konsonan dan suku kata daripada kata pinjaman yang panjang, atau komponen perkataan dalam kata majmuk (misalnya steering-wheel menjadi "stereng") merupakan ciri signifikan dalam proses pembentukan bahasa.

Data

C1D157

\section{Teks Selari I}

Total Care \& Protection Against Tooth Sensitivity!

\section{Teks Selari II}

Penjagaan Menyeluruh \&

Perlindungan daripada Gigi Sensitif!

Berdasarkan analisis data katalog Avon, penulis tidak menemukan sebarang kata pinjaman yang wujud akibat kata pinjaman yang mempunyai lebih daripada dua suku kata yang dipendekkan atau disusun semula. Analisis data katalog Cosway menunjukkan wujud satu data yang mempunyai lebih daripada dua suku kata dalam TS I, tetapi disusun semula ejaannya dan mengalami pengurangan suku kata dalam TS II. Data C1D157 menunjukkan perkataan sensitivity (sen-si-tiv-ity, lima suku kata) menjadi "sensitif" (sen-si-tif, tiga suku kata). Contoh ini juga menunjukkan perubahan kelas kata daripada kata nama (sensitivity) menjadi kata adjektif (sensitif). Perubahan daripada segi bilangan suku kata ini berlaku disebabkan oleh faktor perbezaan antara sebutan, ejaan dan tatabahasa dalam bahasa Melayu dan bahasa Inggeris. Maka perubahan ejaan akan berlaku pada perkataan asing yang dipinjam ke dalam bahasa Melayu dan perubahan itu mesti selaras dengan panduan ejaan yang digariskan dalam PUEBM (1992).

\section{Kesan Kata Pinjaman bahasa Inggeris dalam Tajuk Utama Iklan Versi Terjemahan}

Berdasarkan analisis data, keinggerisan dalam bentuk kata pinjaman wujud dalam katalog bercetak Cosway dan Avon versi terjemahan. Hal ini disebabkan oleh faktor katalog kajian yang terbahagi kepada beberapa bahagian seperti produk kesihatan, alat solek, keagamaan, peralatan elektrik, pakaian dan sebagainya. Bahagian produk kesihatan misalnya menyebabkan wujud pelbagai istilah bidang seperti lesitin, asid hialuronik, bakteria dan akronim seperti CFO, GI dan UTI. Di samping itu, perkataan yang dipinjam daripada bahasa Inggeris seperti moden, eksotik, klasik, hipster dan elegan sering digunakan bagi mempromosikan produk alat solek, minyak wangi dan pakaian.

Kata pinjaman dalam iklan versi terjemahan ini menimbulkan persoalan akan kesan kewujudannya dalam bahasa Melayu. Kajian Fischer (2008) misalnya menunjukkan isu keinggerisan dinilai daripada segi kesan positif dan kesan negatif. Berdasarkan analisis data, penggunaan kata pinjaman sesuai dibincangkan 
daripada dua sisi tersebut. Sisi positif penggunaan kata pinjaman ialah kerja-kerja menterjemah menjadi lebih cepat dan mudah. Hal ini demikian kerana penciptaan perkataan baharu mengambil masa dan terdapat kemungkinan bahawa makna perkataan baharu itu tidak difahami oleh khalayak sasaran iklan. Misalnya, data KPTA membuktikan nama jenama seperti Sweet Honesty tidak perlu diterjemahkan ke dalam bahasa Melayu.

Kesan positif keinggerisan juga tidak terhad pada mengayakan bahasa, sebaliknya turut memberi kelebihan kepada pengguna bahasa. Khalayak di Malaysia menerima pakai kata asing sebagai salah satu perkataan dalam bahasa Melayu. Penggunaan sesuatu perkataan oleh masyarakat turut mempengaruhi kelangsungan sesuatu perkataan, misalnya data KPAL membuktikan terdapat perkataan pinjaman seperti "mesin" yang telah diasimilasikan dalam budaya Melayu. Sifat bahasa Melayu yang dinamik juga memudahkan perkataan asing diserap ke dalam kosa kata bahasa Melayu. Misalnya, data KPSA apabila perkataan asing dipinjam dan mengalami penyesuaian ortografi (sistem ejaan). Secara tidak langsung, kosa kata bahasa Melayu dalam bidang periklanan semakin bertambah dan memudahkan pemindahan maklumat berlaku.

Tambahan pula, pertambahan bilangan kata pinjaman asing ialah perkara biasa dalam sesebuah bahasa yang bersifat dinamik. Bilangan kata pinjaman yang tinggi ini tidak mempengaruhi tatabahasa bahasa Melayu yang telah mantap. Misalnya analisis data KPSA, data KPMA dan data KPAP membuktikan perkataan asing yang dipinjam ke dalam bahasa Melayu mengalami penyesuaian daripada segi ejaan dan seterusnya disesuaikan dengan hukum tatabahasa bahasa Melayu, misalnya hukum DM. Dapatan ini secara tidak langsung memberikan maklumat bahawa peminjaman perkataan asing ke dalam bahasa Melayu mempunyai garis panduan yang khusus. Antara panduan yang boleh dirujuk oleh penterjemah ialah Pedoman Umum Pembentukan Istilah Bahasa Melayu (PUPIBM 2004) dan Pedoman Umum Ejaan Bahasa Melayu (PUEBM 1992).

Daripada sisi negatif kesan keinggerisan pula, analisis data menunjukkan penterjemah menggunakan perkataan pinjaman sehingga mengabaikan padanan terjemahan perkataan yang sedia ada dalam bahasa Melayu. Misalnya penterjemah cenderung menggunakan padanan kata "produk" (product) berbanding padanan kata "barangan" dalam bahasa Melayu, padanan kata "aplikasi" (application) berbanding padanan kata "penggunaan" dalam bahasa Melayu, padanan kata "profesional" (professional) berbanding padanan kata "pakar" dalam bahasa Melayu serta padanan kata "fleksibiliti" (flexibility) berbanding padanan kata "luwes" dalam bahasa Melayu. 
Faktor kurang mahir dengan panduan ejaan bahasa Melayu dan terpengaruh dengan sebutan dalam bahasa Inggeris juga menyebabkan penterjemah melakukan kesalahan sewaktu mengeja kata pinjaman, misalnya data KPAO. Data C3D92 menunjukkan kata lotion diterjemahkan sebagai "losyen" (salah) berbanding ejaan "losen" yang disenaraikan sebagai kata masukan dalam Kamus Dewan Edisi Keempat (2007). Selain itu, terjemahan iklan dalam bahasa Melayu yang dipenuhi dengan kata pinjaman juga memungkinkan khalayak tidak memahami mesej iklan. Misalnya, penterjemah meminjam perkataan trendy ke dalam bahasa Melayu dan menyesuaikan ejaannya mengikut rumus ejaan bahasa Melayu menjadi "trendi". Namun, perkataan pinjaman berkenaan tidak wujud sebagai kata masukan dalam Kamus Dewan Edisi Keempat (2007). Khalayak pembaca sasaran di Malaysia juga berkemungkinan tidak memahami konsep yang dibawa oleh perkataan "trendi" dalam bahasa Melayu.

\section{Kesimpulan}

Dapatan kajian menunjukkan katalog bercetak Cosway dan Avon mengandungi enam kategori kata pinjaman bahasa Inggeris. Kata pinjaman ini boleh diperincikan kepada kategori KPTA, KPSA, KPAL, KPAO, KPMA dan KPAP. Kategori KPMC tidak wujud dalam data kajian. Selain itu, peminjaman perkataan bahasa Inggeris dalam terjemahan tajuk utama iklan bagi katalog bercetak Cosway dan Avon mempunyai kesan positif dan negatif.

Walaupun data kajian membuktikan isu keinggerisan berlaku dalam penterjemahan katalog bercetak di Malaysia, bahasa Melayu masih berkemampuan untuk menjadi lingua franca industri periklanan. Hal ini disebabkan oleh media, khususnya media iklan mampu mendidik setiap warga Malaysia dalam hal berkaitan bahasa Melayu baku dan kesantunan berbahasa (Raja Masittah 2017). Pihak Dewan Bahasa dan Pustaka (DBP) misalnya menyediakan pelbagai rujukan dan kaedah bagi memastikan bahasa iklan yang digunakan tepat ejaan, tatabahasa dan santun bahasanya. Misalnya ruangan Khidmat Nasihat, Pengesahan Bahasa dan Pantau Tegur Bahasa dalam laman sesawang DBP membolehkan pelbagai pihak menyuarakan kemusykilan berkaitan bahasa Melayu, peristilahan dan penterjemahan.

Di samping itu, rujukan "Tatacara Pengesahan Bahasa Kebangsaan dalam Iklan" yang dimuatkan dalam laman sesawang DBP membolehkan para pengiklan atau masyarakat awam mendapatkan panduan berkaitan proses pengesahan bahasa dalam iklan (DBP 2015). Rujukan buku Nama Khas dan Iklan (Ismail 1997) terbitan DBP juga boleh digunakan dalam penamaan produk, sama ada dengan memilih kosa kata klasik dan moden dalam bahasa Melayu. Pelbagai unsur flora 
dan fauna, bahasa serta budaya tempatan juga sesuai dijadikan sumber dalam penamaan produk berbanding menggunakan nama yang berunsur keinggerisan dalam penamaan produk tempatan.

\section{Penghargaan}

Penulis merakamkan penghargaan kepada Universiti Sains Malaysia atas pembiayaan kajian ini di bawah Geran Penyelidikan Jangka Pendek (304/ PHUMANITI/6315017).

\section{Rujukan}

Asmah Omar. 1984. Bahasa iklan perniagaan. Satu kajian bahasa retorik. Kuala Lumpur: Dewan Bahasa dan Pustaka \& Kementerian Pelajaran Malaysia.

Basem Abbas Al Agha. 2006. The translation of fast-food advertising texts from English into Arabic. Master's thesis, University of South Africa, Pretoria, South Africa, uir.unisa.ac.za/bitstream/handle/10500/2325/dissertation.pdf(accessed 7 May 2013).

Bolen, W.H. 1984. Advertising (2nd ed.). New York: John Wiley \& Sons, Inc.

DBP (Dewan Bahasa dan Pustaka). 2015. Tatacara pengesahan bahasa kebangsaan dalam iklan. http://eseminar.dbp.gov.my/dokumen/tatacarapengesahan.pdf (accessed 12 August 2015).

Fischer, R. 2008. Introduction: Studying anglicisms. In Anglicisms in Europe, eds. R. Fischer and H. Pułaczewska, 1-15. New Castle: Cambridge Scholars Publishing. Haslina Haroon. 2006. Aspek terjemahan dalam iklan di Malaysia. In Dinamika media dan masyarakat Malaysia, eds. Mohamad Md. Yusoff, Kamaliah Siarap, Azman Azwan Azmawati, Muhammad Hatta Muhammad Tabut and Juliana Abdul Wahab, 38-51. Pulau Pinang: Penerbit Universiti Sains Malaysia.

Haugen, E.I. 1972. The ecology of language: Essays by Einar Haugen, ed. Anwar S. Dil. Stanford, California: Stanford University Press.

Heah, C.L.H. 1989. The influence of English on the lexical expansion of bahasa Malaysia. Kuala Lumpur: Dewan Bahasa dan Pustaka.

Ismail Dahaman. 1997. Nama khas dan iklan. Kuala Lumpur: Dewan Bahasa dan Pustaka. Kamus Dewan Edisi Keempat. 2007. Kuala Lumpur: Dewan Bahasa dan Pustaka.

Kamus Linguistik (1st ed.). 1997. Kuala Lumpur: Dewan Bahasa dan Pustaka.

Larson, M.L. 1984. Meaning-based translation: A guide to cross-language equivalence. New York and London: University Press of America.

Majlinda Nuhiu. 2014. Anglicisms in the Albanian mass media in the Republic of Macedonia. European Journal of Research on Education 2(1): 19-23. http://iassr. org/rs/020303.pdf (accessed 1 October 2014).

Maserah Shabudin and Idris Aman. 2012. Wacana dan ideologi iklan produk kecantikan berbahasa Jepun. GEMA Online ${ }^{\circledR}$ Journal of Language Studies 12(3): 789-816.

Mohd. Sidin Ahmad Ishak and Noorbathi Badaruddin. 1993. Asas periklanan. Kuala Lumpur: Dewan Bahasa dan Pustaka. 
Nathesan, S. 2015. Etimologi bahasa Melayu. Kuala Lumpur: Dewan Bahasa dan Pustaka. Newmark, P. 1988. A textbook of translation. New York: Prentice Hall.

PUEBM (Pedoman Umum Ejaan Bahasa Melayu). 1992. Kuala Lumpur: Dewan Bahasa dan Pustaka.

PUPIBM (Pedoman Umum Pembentukan Istilah Bahasa Melayu). 2004. Kuala Lumpur: Dewan Bahasa dan Pustaka.

Puteri Roslina Abdul Wahid. 2012. Menelusuri peristilahan bahasa Melayu. Kuala Lumpur: Penerbit Universiti Malaya.

Raja Masittah Raja Ariffin. 2017. Kesantunan bahasa dalam media penyiaran di Malaysia. In Perancangan bahasa. Ideologi bahasa Melayu, ed. Nik Safiah Karim, 181-197. Kuala Lumpur: Dewan Bahasa dan Pustaka.

Smith, K.L. 2002. The translation of advertising texts: A study of English-language printed advertisements and their translations in Russian. $\mathrm{PhD}$ dissertation, University of Sheffield, United Kingdom. etheses.whiterose.ac.uk/3044/2/251329_VOL1.pdf (accessed 17 February 2014).

Torresi, I. 2010. Translating promotional and advertising texts. Manchester: St. Jerome. 